Article

\title{
Tabish Khair's Just Another Jihadi Jane: Western Civilization and 'War on Terror' Versus Islamist Terrorism as the Two Sides of the Globalization Coin
}

\author{
Dolores Herrero \\ Department of English and German Philology, University of Zaragoza, 50009 Zaragoza, Spain; \\ dherrero@unizar.es; Tel: +34-976-761-523
}

Received: 21 July 2018; Accepted: 30 September 2018; Published: 2 October 2018

\begin{abstract}
Armed conflicts and violence have always been concomitant with human history but it is undeniable that our perception of them has undergone some disturbing evolution of late. Whereas in the past wars and organized violence were mainly regarded as being temporary, that is, originating in a number of reasons and tensions that might become eventually solved and confined to very specific zones on the world map, nowadays most people feel that nobody can escape the scourge of indiscriminate violence and this is mainly due to terrorism, in particular to that associated with Muslim fundamentalism. The aim of this paper will be to discuss the origins of this form of terrorism, together with its inextricable relationship with the so-called 'civilized' West, putting the emphasis on its more secular aspects and implications so as to show how Tabish Khair's novel, Just Another Jihadi Jane denounces the effects that this conflict can have upon average people, all the more so if they happen to be Muslim women living in the western world.
\end{abstract}

Keywords: war versus Islamic terrorism; globalized capitalism; West versus Islam; desire for the West; jihadi brides; suicide bombers

\section{Introduction}

Islamist terrorism has no doubt become the source of global fear, the West's insidious 'Other,' and consequently threatens to undermine the peace and stability that its sworn enemy, namely, the so-called 'civilized' world and more particularly global capital, require in order to thrive and supposedly lead the way to ever-increasing prosperity and progress. Ours is an age of increasing interconnectedness, not only of goods, ideas and persons but also of terror. It is this deeply ingrained sensation of vulnerability that has prompted many western readers to show interest in fiction that delves into the threat of Islamist extremism and, above all, in the complex, even schizophrenic, cultural and political reality of immigrant Muslim communities in western societies. In keeping with some of the main concerns of well-known novels like Mohsin Hamid's The Reluctant Fundamentalist (2007), Tabish Khair's Just Another Jihadi Jane (2016) gets inside the minds of people westerners are eager to know more about but do not dare to fully approach and strives to decipher the ultimate reasons for some of them to undergo the mental process that will finally lead them to embrace the most radical interpretation of Islam and join the jihad, this being understood as the 'just war' against the enemies of their culture and faith. However, as Khair's novel strives to demonstrate, no matter how many binary oppositions in connection to either western or Islam tenets are articulated (West/civilization/rationality/human rights vs. Islam/barbarity/madness/oppression), they only seem to beget mutual ignorance, distrust and hatred, with the result that, very often using religion and fair retribution as an excuse, violence escalates equally and relentlessly on both sides. And here lies the paradox: in spite of their differences, or mainly because they are not that different after all, extremes meet: civilization is side by side with barbarity 
and holiness goes hand in hand with impiety and extreme cruelty. To put it differently, the Other is an unquestionable part of the Self, which the latter refuses to recognize, acknowledge and accommodate. Self and Other, or civilization and terrorism in this case, are nothing but the two sides of the same coin and inexorably need each other to make sense of themselves. It is only growing awareness of this fact that will pave the way for some kind of rapprochement, however fragile this may be, in the (hopefully not so distant) future.

The main aim of this paper will be to briefly analyze the similarities and differences between war and terrorism, together with the origins and meaning of Islamist radicalism, so as to better accomplish the study and interpretation of Tabish Khair's novel Just Another Jihadi Jane. By mainly focusing on the secular aspects and implications of the Daesh movement, Khair's latest novel attempts to denounce the lethal effects that this terrorist group can have on ordinary Muslims, all the more so if they happen to be women and live in the western world. In order to do so, special attention is paid to the important role played by the internet and the media in its widespread dissemination and strengthening, and also to the so many contradictions that lie at the core of the Islamist creed that they strive to enforce upon non-radical Muslims and non-Muslims alike, which often lead some of their leaders to emulate and yearn for the West, whether consciously or unconsciously, and to incite others to become suicide bombers in order to safeguard their own interests and power.

\section{War versus Terrorism}

Living in terror is not a universal experience, it is true. Yet, it is a fact that more and more people (westerners in particular) cannot do away with the sensation that, in the ever-increasing technological/digital/globalized era we are living in, old notions of war should be reconsidered and reformulated (see Münkler 2005 [1]; Kaldor 2006 [2]; Gray 1997 [3]), as they feel they are constantly at risk and, accordingly, rather more vulnerable than before. Such is the menace posed by Islamist terrorists today that many western leaders, in keeping with the words uttered by President Bush on the aftermath of the attack on the World Trade Centre and the Pentagon, have come to conclude that their actions are "more than acts of terror. They [are] acts of war" [4] ((p. 7); emphasis in original). Although a number of studies have been published on the nature of terrorism (see, for example, Guelke 1995 [5]; Kubiac 1992 [6]; Zulaica and Douglass 1996 [7]), there is still no internationally accepted definition of it, especially when this takes on world-wide dimensions, nor a clear distinction between terrorism and war. Maybe due to this, the question of how 'terrorism' and 'war' are understood and used in contemporary public discourse should be taken into serious consideration. In his seminal book Arguing about War (2004), political philosopher Michael Walzer establishes a very clear distinction between both. As he sees it, war is a legal activity providing that it fulfils certain conditions: self-defense, honoring a treaty obligation towards a state that has been attacked and so forth. On the contrary, terrorism is always illegal, he adamantly affirms, because it is an indiscriminate attack upon the innocent and therefore "worse than rape and murder commonly are, for in the latter cases the victim has been chosen for a purpose [ . . ] however twisted or ugly it may be" [8] (p. 51). According to Walzer, "the peculiar evil of terrorism" is, above all, "the intrusion of fear into everyday life, the violation of private purposes, the insecurity of public spaces, the endless coerciveness of precaution" [8] (p. 51). To put it differently, both nation-states and terrorist groups kill but the former claim to do so legitimately. It is obvious, Asad retorts [4] (p. 16), that Walzer fails to see a clear contradiction at the heart of the western culture of war which, on the one hand, upholds the state's need to legitimize institutional violence against a collective enemy (civilians included) and, on the other, advocates the sacrosanct humanitarian desire to save human lives. In order to move beyond the impasse that this inevitably generates, Walzer explains that this humanitarian desire can only be and often is, overlooked in the event of what he labels as "supreme emergency" [8] (p. 33), to then make it clear that overriding the rules is by no means free, as it must always bring out a strong sense of guilt "as a recognition of the enormity of what we have done and a commitment not to make our actions into an easy precedent for the future" [8] (p. 34). Moreover, he speaks in favor of 
the figure of the "morally strong leader," which he defines as "someone who understands why it is wrong to kill the innocent and refuses to do so, refuses again and again, until the heavens are about to fall. And then he becomes a moral criminal (like Albert Camus's 'just assassin') who knows that he can't do what he has to do -and finally does" [8] (p. 45). This leader, Walzer goes on to argue, relies, whenever necessary, upon "emergency ethics," which basically means "that we recognize at the same time the evil we oppose and the evil we do and that we set ourselves, so far as possible, against both" [8] (p. 49). As can be easily guessed, the main problem here is how 'so far as possible' should be understood. In his opinion, the leaders of a political community can only confront a potential evil by doing evil when they feel the compulsive need to protect the community itself, or rather, the state, as it is the latter that actually regulates, represents and protects a community of citizens: the state sanctions the killing of human beings, demands that its citizens should sacrifice their lives in times of war and ultimately determines the desired territorial extent for the community that it embodies and serves. However strongly Walzer tries to put forward his arguments, though, they cannot help sounding rather cynical: as is well known, the military of a liberal state often targets facilities that are crucial, not only to the enemy's military but also to civilians; makes use of torture to obtain strategic information; and generally considers cruelty to be more acceptable when this is used against the 'barbarians,' that is, those who do not belong to the 'civilized' West. All in all, as Asad contends, "it is not cruelty that matters in the distinction between terrorists and armies at war, still less the threat each poses to entire ways of life but their civilizational status. What is really at stake is $[\ldots]$ the fight of civilization against the uncivilized" [4] (p. 38). Once again, the irony is that, in that fight, civilization feels wholly entitled to leave all civilized rules behind, thus rendering inhuman acts humane. A prerogative with which the so-called 'Muslim savages,' whose reasons to kill can sometimes be very similar to those put forward by the West, are never endowed.

\section{The 'Enigma' of Islamist Terrorism: Its Origins and Raison D'être}

If, as Badiou reminds us [9] ((p. 9); emphasis in original), "nothing that anyone does is unintelligible," it is no use affirming that Islamist terrorism is impossible to understand and, by extension, impossible to account for and think because, as this thinker goes on to argue, "the declaration of the unthinkable is always a defeat of thought and the defeat of thought is always precisely the victory of irrational and criminal behaviors" [9] (p. 9). In other words, we will only be able to neutralize and defeat terrorism if we manage to understand and articulate the reasons why it actually began. Many contemporary political scientists, such as Patrick Sookhdeo [10] and Lee Harris [11], to give but two examples, have chosen to understand terrorist attacks and in particular the conflict between the West and Islamist fundamentalism as a 'clash of civilizations,' thus clinging to the thesis originally put forward and subsequently popularized by Anglo-American orientalist Bernard Lewis. As Lewis explained [4] (p. 9), in the first, conquering phase of Islamic history the organized violence called jihad was basically an expression of Muslim intolerance towards non-Muslims. With the passing of time, however, as Islamic civilization gradually declined and the West ended up taking the upper hand, Islamist violence mainly turned into a fanatical resentment against modernity. For those who support this interpretation, then, the danger of terrorism will remain as long as the Islamic world refuses to become radically transformed/modernized.

However convincing this thesis of the clash of civilizations may sound, Asad retorts [4] (pp. 10-13), it is nonetheless obvious that it fails to take into account an important history of mutual borrowings and interactions among Christians, Jews and Muslims. Secondly, this assumption somehow implies that the identity of a people, as either European or Islamic, almost exclusively depends on a selective cultural heritage with which most of them, including the intellectual elite, are not wholly familiarized. Thirdly, it must be noted that, unlike the Christian papal monarchy, which cared and managed to impose a monolithic religious discourse, in the Islamic world there has never been a centralized theological authority, which accordingly means that there was never a consensus as regards, among other things, the virtue of religious warfare. As a matter of fact, many Muslim jurists have 
often claimed that the jihad can only be justified when Islam is genuinely threatened and no other way to defend it can be envisaged. As Asad, in tune with many other relevant critics, such as Edward Said [12], Amin Maalouf [13] and Pankaj Mishra [14], to name but some, concludes, there is no point in talking about the clash of civilizations because "there are no self-contained societies to which fixed civilizational values correspond" [4] (p. 12). Instead, we should regard the mercenary penetration and imposition of European economic, political and ideological standards upon the Middle East since the very beginning of the nineteenth century as the main source of on-going conflict and tension between both worlds (see also Hafez [15]). Asad explains this as follows:

European states conducted their strategic and commercial rivalries throughout the lands of a weakened-and eventually broken-up-Ottoman Empire, building and controlling transport systems (the Suez Canal being the most important), promising and establishing a national home in Palestine to the Jews, dividing up the Middle East into mandates and spheres of influence, making unequal treaties with sovereign Arab polities, exploiting petroleum resources and so forth. The United States has simply continued in this interventionist tradition with its own strategic and economic interests [4] (p. 13).

It is not enough, then, to claim that Muslim-majority countries are in dire need of reform, however true this may be; the West (that is, Europe and the United States) should also reconsider and mitigate, not only the lethal effects that many of their policies have had and are still having on the Muslim world, but also the biased information often provided by academics, columnists and journalists who find that, in Said's words, "the market for representations of a monolithic, enraged, threatening and conspiratorially spreading Islam is much greater, more useful and capable of generating more excitement" [12] (p. 28). For his part, Baudrillard [16] (p. 97) sees this clash, not as one of civilizations, but rather as an almost anthropological confrontation between a culture that claims to be universal, and thus threatens to reduce all of its cultural Others to an undifferentiated and global version of itself/the Same (the West), and another culture that adamantly refuses to assimilate in order to cling to its irreducible alterity (Islam). Paradoxically, Baudrillard explains:

The transition from the universal to the global is both a homogenization and a fragmentation to infinity. The central gives way not to the local but to the dislocated. The concentric gives way not to the decentered but to the eccentric. And discrimination and exclusion are not accidental consequences; they are part of the very logic of globalization [16] (p. 90).

The triumph of unrestrained globalized capitalism, which claims to be the one and only reasonable path for the progress of humanity, together with the subsequent weakening of the nation-states and the resulting new practices of imperialism ought to be considered, according to Badiou [9], as the true origin of this form of terrorism. As this thinker explains [9] (p. 19), the liberalization of capital takes two forms, which are in constant dialectical movement: on the one hand, globalization, this being understood as the ever-increasing expansion of capitalism to whole territories of the world; on the other hand, the extraordinary power of the concentration of capital. In a word: capital spreads and in spreading it concentrates. These concentrations eventually create new transnational poles of power, rather more powerful than the traditional nation-states, which are thus reduced to acting as mere local managers of this vast global structure. Furthermore, what is coming into view, Badiou goes on to argue [9] (pp. 27-29), is the progressive destatization of globalized capitalism, that is, the possibility that states should be destroyed (what he labels as 'zoning') so that world firms can operate without any kind of control or restrictions. To put it differently, this new kind of imperialism fabricates infra-state zones that in fact are areas of non-state pillaging, whose management and control may demand some military intervention every now and then but no true responsibility. Obviously, the first effect of all of this is unequal development and by extension lack of democracy [9] (pp. 31-37). The figures speak for themselves: whereas $1 \%$ of the global population possess $46 \%$ of the available resources (that is, almost half) and $10 \%$ possess $86 \%, 50 \%$ possess nothing and are accordingly counted for 
nothing by capital -as they are nothing, they should not exist, should not be there, but the problem is that they are there all the same. Interestingly enough, most dispossessed people are clearly linked to 'zoning.' As regards the middle classes, largely concentrated in the so-called civilized/western countries and thus the true pillar of democracy, they represent $40 \%$ of the population but must share between them $14 \%$ of global resources. This explains why they are afraid of an invasion on the part of the destitute and thus so prone to racism and xenophobia. As Badiou sees it [9] (pp. 44-49), the structure of the contemporary world produces three types of subjectivities: (1) Western subjectivity, that is, the subjectivity of the rich and middle classes, who are very proud of themselves and their developed countries but live in constant fear to become invaded and pauperized; (2) the subjectivity of desire for the West, namely, that of those who own nothing and are constantly exposed to the luxury and arrogance of the members of the first group, which results in their bitter frustration, often involving a mixture of envy and revolt; and (3) a nihilist subjectivity, characterized by desire for revenge and destruction and obviously coupled with the desire for departure and alienated imitation, often expressed and formalized in reactive mythologies and the exaltation of fundamentalisms that aim to destroy the western way of life, the desire for the West. The outcome of this frustration is, Badiou claims [9] (pp. 51-52), contemporary fascism, a reactive and intra-capitalist subjectivity, since it is embedded in the world market and proposes no alternative structure of the world but reproaches capitalism for not being able to keep its promises. The practical form of these fascisms is, more often than not, the logic of the gang, which goes hand in hand with the need to conquer and control territories or business monopolies. As can be guessed, it is the youths with no prospects, with no place in modern society that mainly undergo this fascization/radicalization process, which implies an impossible mixture of sacrificial and criminal heroism and western luxuries. Consequently, modern fascism should be seen as a death drive articulated in a language of identity, religion being a very important ingredient of this. However, as Badiou warns, religion is only "a cover, it is not at all what is at the bottom of all this, it is a form of subjectivation but not the real content of the thing" [9] (p. 52); religion "can perfectly well act as an identitarian sauce for all of this, precisely in so far as it is a suitably anti-Western referent" [9] (p. 55). Contrary to what many people may think, the ultimate meaning of this is that "it's fascization that Islamizes, not Islam that fascizes" [9] (p. 56). Truly nihilism is always at the core of terrorist murderousness: since their own lives do not count, the lives of others mean nothing to them either. The suicidal form of crime takes the death drive to its lowest point and ultimate consequences; in the end, nothing and nobody is left. Finally, when it comes to distinguishing between barbarity and civilization, Badiou cannot be any more eloquent:

As for war, one thing is clear: it is not 'barbarians' who have declared war; it is the [European states] that, in the wake of private firms and sometimes the Americans, [have] gone to mix [themselves] up in murky imperial affairs, to participate in zoning, to destroy states and which in doing so [have] created the [... ] situation [...] [that] includes the subjective genesis of young fascists in the zones devastated of any social life and the fact that a whole segment of the global population is counted for nothing [9] (p. 67).

In keeping with the main Marxist axiom, it could be argued that the capitalist system begets its own monsters and contains the seeds of its own annihilation. Global capitalism and Islamist terrorism are, therefore, the two sides of the same coin: they need each other to coexist in a perverse dialectics of mutual need and exclusion. As Baudrillard concludes [16] (pp. 8-9), when global power monopolizes the situation and allows for no alternative form of thinking, the result is no other than a "terroristic situational transfer," which he explains as follows:

It was the system itself which created the objective conditions for this brutal retaliation. By seizing all the cards for itself, it forced the Other to change the rules. And the new rules are fierce ones, because the stakes are fierce. To a system whose very excess of power poses an insoluble challenge, the terrorists respond with a definitive act which is also not susceptible of 
exchange. Terrorism is the act that restores an irreducible singularity to the heart of a system of generalized exchange [16] (pp. 8-9).

Contrary to what the Enlightenment philosophy believed, the progress of Good does not correspond to a defeat of Evil. The mature Jamilla in Khair's novel knows this so well that at one point she asserts: "Goodness has to live with the possibility of evil, not eradicate it. [ ... ] [W] hen goodness wants to become pure and alone, that is when it turns evil, truly evil; not the grubby evil that it has to tolerate in order to be goodness but Evil itself" [17] (p. 118). In tune with this, Baudrillard concludes: "Good does not conquer Evil, nor indeed does the reverse happen: they are at once both irreducible to each other and inextricably interrelated" [16] (p. 13). By seizing for itself a global monopoly of power, the West triggers off Islamist retaliation attacks of similar intensity, whose ultimate aim is to defy the system by enacting a symbolic and sacrificial death to which the West cannot respond except by its own death and its own collapse.

\section{East versus West in Just Another Jihadi Jane}

\subsection{Women's Fate}

As a number of scholars have made clear (see, for example, Kassam 2010 [18]; Hafez 2011 [19]; Taylor 2017 [20] and Falah 2005 [21]), there is no such thing as 'the Muslim woman.' Factors as diverse as cultural, political, economic and geographical must be taken into serious consideration, not only when trying to understand the situation and role of Muslim women in their respective societies, but also in order to challenge and put to the test many stereotypes and assumptions so often invoked, both in traditional societies and the West. Yet, the dichotomy East versus West, together with its concomitant cultural and psychological implications, is of the utmost importance when it comes to analyzing the lives of Muslim women living in western countries. It is this dialectic duality that Tabish Khair's novel mainly strives to bring to the fore. At the very beginning, Jamilla, the Muslim woman who retrospectively tells her own story and that of her friend, Ameena, to the writer who will later on write a novel on them, makes it very clear that there is no monolithic and unquestionable truth and that, however close both of them may have been, they nonetheless had rather different attitudes towards life: "Remember, I am a woman who started off with the conviction that there should be nothing but truth. The One Truth, the Only Truth. I was suckled on that conviction. Ameena wasn't. I felt I had the truth; Ameena was seeking the truth" [17] ((p. 1); emphasis in original). These two women's convoluted stories are told in ten chapters, which carefully narrate their journey from West to East, together with the different evolutions that each one of them underwent as a result. Chapter 1, "Reading Scheme," Chapter 2, "My Brother's Wedding," and Chapter 3, "Amina's Flat," describe the lives of these two Muslim teenagers in Britain: how they met and made friends, their different conceptions of life and their relationships with their school mates, teachers, families and the English people living in their vicinity. The first climatic moment comes when Ameena, having failed to fully assimilate to western ways, decides to leave Britain and go to Syria in order to join the jihad by marrying a radical Islamist. On the other hand, Jamilla, the very traditional but by no means extremist Muslim girl who played a crucial role in Ameena's transformation, seems to baulk at adhering to Islam customs, which clearly demand that she should marry at a young age, and prefers to get a degree instead. However, her father's death and her subsequent inability to get any kind of study grant finally lead her to join Ameena in her jihadist adventure. Chapter 4, "The Flight," describes their trip from Istanbul to the Middle East and Jamilla's expectations. In Chapter 5, titled "A New Life," Jamilla feels quite satisfied with her decision: her life in Syria is ordered, simple, pure and has a clear purpose. Although she will soon become acquainted with the strict Islamist routine and the radical interpretation of Islam enforced by Daesh, she decides not to doubt. Chapter 6, "Halide," and Chapter 7, "The Prisoners" lead on to the final revelation. The orphanage in which they live suddenly turns into a prison and "simplicity" into "meagerness" [17] ((pp. 135-136); emphasis in original). Daesh cruel aims are fully disclosed through the punishment and sorry fate of Halide, a most kind and innocent 
Muslim female orphan who dared to question their radical interpretation of Islam, and the irruption of two Peshmerga (Kurdish) female soldiers into the orphanage as prisoners. Jamilla starts missing the West and finds it more and more difficult to trust anybody there, including the newly arrived Ameena. Chapter 8, "Jihadi Bride," is a flashback in which Jamilla narrates Ameena's story as if told by her friend. The determined and idealist Ameena who arrived in Syria to take part in the jihad eventually becomes an abused and ill-treated jihadi wife. In her loneliness, she becomes very close to Sabah, a Yazidi boy whom her husband constantly bullies as if he were his slave. Ameena's unexpected encounter with violence and utmost cruelty undermines her beliefs and prompts her desire for revenge. Chapter 9, "The Sounds of War," and Chapter 10, "Suicide Bomber" pave the way for the final and most unexpected denouement: Jamilla cannot cling to that faith anymore and, paradoxically, Ameena's attitude drastically changes. When the orphanage becomes under siege, Ameena thinks of a plot to take Jamilla out of that hell and kill all the other Daesh members: much to Jamilla's horror, she says that both of them offer to become suicide bombers. In the end, however, it is Ameena who immolates herself so that her friend and the two Peshmerga soldiers can break free. The novel ends with a deeply moved and rather more mature Jamilla living in Indonesia. Unable -and unwilling- to go back to England, she clings to her freedom and newly acquired Sufi faith in the one and only company of her cat, Batala.

As is shown in the first Chapter, both girls live in the same derelict neighborhood, formerly inhabited by poor working-class English people, who made no secret of the fact that they despised them and their difference:

The lift would smell of vomit and beer then. And there were used condoms and syringes lying about. Then, of course, more of us moved in and more of them moved out. Some were glad to leave; some gave us the finger. But they left, slowly, one by one, the so-called white working class. Or the white drinking class. The so-called brown working class moved in. It was not the brown drinking class though; it was mostly the Muslim working class. The smell of vomit and beer disappeared. The syringes and condoms disappeared. The graffiti got multilingual. All the rest stayed as it was [17] (p. 3).

Jamilla's father suffered xenophobia in his own flesh, as when he "had a swastika spray-painted on his cab one night, its windows smashed and they had trouble getting insurance to cover the expenses" but, on the whole, accepted "such trials [ ... ] as part and parcel of his working life" [17] (p. 21). As far as Jamilla is concerned, she makes it clear that "no man, not one Muslim man, no matter how believing, how faithful, how orthodox, has to face a third of the difficulties that orthodox Muslim women encounter in the West" [17] (p. 77), where they are often regarded as either "a monster or a curiosity" [17] (p. 78). This is the way she felt when, one day as she got off the bus, an old woman berated her for being dressed the way she was, shouting "Yew are le'in' down all women, yew idiot" [17] (p. 73).

These racist episodes notwithstanding, the novel points to Ameena's lack of affection and self-respect and Jamilla's lack of future prospects as the main reasons for their respective 'Islamization' processes. Ameena was the ugly duckling that desperately tried to assimilate to western ways: she smoked, hung out with any boy who gave her some attention, "used to go about with the dregs of her previous neighborhood" [17] (p. 11) and went as far as to lose her virginity in order to be accepted by her school peers but all in vain. To make matters worse, her parents divorced and were rather different: whereas her father was a successful man who could afford to have one white girlfriend after another, her mother "toiled hard as a teacher," "was either in a rush or tired, which made her complaining, inattentive or irritable," and her flat was rather messy, "with books, magazines and plates scattered everywhere" [17] (p. 10). Jamilla brings to the fore Ameena's real reasons to join the jihad when she wonders: "are you sure it was the mosque that radicalized Ameena? [ . . . ] Or was it also Ameena's parents' divorce? Was it that ghostly hurt and anger lurking in Ameena's lucid eyes? Was it her lost love for Alex? Was it the way her friends snubbed her?" [17] (p. 26). As regards Jamilla, she had so far lived comfortably enough in her traditional Muslim family. However, when, after her father's death, her brother decided to marry and in turn marry her off so that he could keep the family flat for himself and his new wife, she suddenly 
"felt the burn of resentment" [17] (p. 68) towards him and, indirectly, also towards her mother, who did nothing to protect her and her interests. After all, her mother "never seemed to have a real opinion. She was a timid woman [ ... ] who had been lovingly browbeaten by her father and then her husband and then this incomprehensible new country. In due course, she would be lovingly browbeaten by her son, too" [17] (p. 4). Having been disinherited, Jamilla started applying for college grants as her only means to escape an unwanted marriage, but eventually got "no scholarship, no funding of any sort" [17] (p. 66). No matter how adamantly she clung to the belief that she needed to escape the evil West in order to live a good Islamic life, it was this lack of interest on the part of both her family and English society that ultimately prompted her to accompany Ameena to Syria.

The fate that awaits the women that join the jihad is no better, though. To begin with, they are regarded, all the more so if they happen to be westerners, as mere war trophies, "a victory of sorts, an endorsement" [17] (p. 83). Secondly, they are soon classified into several categories, mainly on account of their usefulness to the movement, as if they were commodities that can be easily used and disposed of. In the Syrian orphanage, for example, there were three kinds of women: older women, whose main function was to teach the younger ones; (mostly beautiful) younger women, who were meant to be brides; and (mostly uglier) girls, who were trained to be suicide bombers [17] (p. 127). As regards those who ended up marrying a member of the jihad, they had to make sure that their husbands thought that they were virgin (this is why Ameena buys artificial hymens before going to Syria) and often had to put up with the institution of polygamy, from which only the oldest wife might benefit, since the younger ones had to obey and "execute her commands with absolute obedience" as if they "were each the perfect combination of sister and slave to her" [17] (p. 94). In the worst of cases, they could be raped, on the grounds that, as one imam explains, "a woman without a man was weak and fallible; and surely if a woman in such circumstances could not have a husband, she was still safer in the care of an honorable man of the faith, who would satisfy her womanly needs and protect her at the same time" [17] (p. 184). All Muslim women are supposed to belong in a hypothetical Islamist community but, in fact, they have very little in common. Jamilla's thoughts speak for themselves:

what $[. .$.$] did we really have in common with the Somalian girl who refused to read$ anything but the Qur'an, the Algerian girl whose Islamism was driven by colonial memories of French atrocities instead of any firm religious belief, the Palestinian woman who had given up on moderate politics because she was convinced that Israeli and American politicians were lying about the two-state solution? Or, for that matter, with green-eyed Michelle, a stunning nineteen-year-old brunette from a Parisian suburb, a self-confessed 'film buff' who had converted to Islam after an online romance with a jihadi she had never met and who daydreamed of a future fighting by his side [17] (p. 54)?

Generalizations are only used to reduce what is extraordinarily complex to the same, in short, to better control female diversity with a view to fully manipulating women, no matter where they come from or the culture and community they belong to.

\subsection{The Internet and the Media}

It is clear that individuals and groups that emphasized their 'Muslimness' were pioneers in the use of the new media. As Jon W. Anderson sees it [22], this might be attributed to the fact that many Muslim students in the United States happened to be studying at universities that would soon play an important role in the development and promotion of the Internet. According to the studies carried out by Bunt [23] and Roy [24], Muslims from different ethnic, linguistic, religious and political backgrounds are using the Internet for discussing Islam and Muslim issues and for apologetic or polemical reasons. In addition, more and more Muslim scholars, together with established Islamic institutions, such as the Sunni Muslim Al-Azhar University in Cairo, Egypt, have also decided to use the Internet to enforce their interpretations of Islam. It has also become crucial to reach out to individuals of Muslim cultural background who live in western countries. The transnational nature of this phenomenon has also been 
brought to the fore in several studies, such as Mandaville [25], that directly or indirectly discuss Islam, Muslims and the Internet. The Internet makes it possible to explore and find alternative interpretations of Islam, or simply to ask questions about Islam but it is also obvious that this can be regarded as dangerous by religious authorities and political leaders, since the Internet caters for individuals and groups with rather different interests and political and ideological orientations. The ever-increasing complexity of the new media are emphasized in Eickelman and Anderson [22] and Larsson [26], which deal with Islam, the Internet and the new media in local, global and transnational contexts. It is also evident that a high number of Muslim preachers are using the Internet to promote their specific interpretations of Islam.

Khair is, once again, well aware of this. That is why in Just Another Jihadi Jane he also attempts to illustrate that the war between the West and the Islamist world is also or, rather said, mainly waged on the media and, more particularly, on the Internet. As has often been argued, there are two sides to them, especially to the latter: on the one hand, they can allow for the manipulation and distribution of (often encrypted and/or manipulated) information and propaganda between far-away places and peoples, who can thus be easily led to believe in falsehoods; on the other, they can become a link that brings emotionally together people who, being overwhelmingly non-westerners, would not be able to do it otherwise. As Jamilla explains:

You read articles about how the Internet has created a lonelier world, with people isolating themselves behind their screens, connecting through a flat keyboard rather than in a park or at a party. Yes and no, yes and no. It depends on who you are and where. Some of us never had parks or parties to connect in. Some of us never will [17] (p. 98).

Each side makes the most of the Internet to spread their own interpretation of facts, in such a partisan way that, more often than not, their versions fully contradict one another and only care about circulating the news they want the rest of the world to believe and creating sounding boards within which only the echoes of their own voices can be heard. As Jamilla denounces, such are the intensity of these exchanges and the difficulty to verify their certainty that "it was difficult to distinguish between truth and propaganda before I joined the jihadis and it became [ . . . ] even more difficult to do so when I was with them. [ . . ] there are too many official liars on all sides" [17] (p. 101). The West insists on demonizing Muslims, blaming them for terrorist attacks and the killing of innocent boys and girls [17] (p. 50) and exaggerating the numbers of western women who join the jihad, "as if all Muslim women in Europe were about to jump on planes to Istanbul" [17] (p. 80). As a matter of fact, most of the western sources of information are "'embedded' reporters, catering to their governments' requirements in most cases and blinded by their own cultural assumptions in almost all" [17] (p. 55). On the other hand, the Internet offers to all the Muslims who feel excluded and despised by all that the West represents "an entire world out there in which [they] were the norm, not the exception" [17] (p. 53) and to the jihadis the means to keep their followers under absolute control. Once in the orphanage in Syria, Jamilla and the rest of girls can only use the Internet room "occasionally" and "under supervision" [17] (p. 96) and, when they are given permission to have access to the news, it is only to those that "would be of use to [them], nothing 'degenerate' or 'Western'" [17] (p. 114). They are not allowed to contact their families, not even to tell them that they are still alive. Furthermore, their former e-mail, Twitter and Facebook accounts are either closed or discontinued, and it is only their recently created jihadi personas that they can retain to ensure non-stop indoctrination: "Our jihadi-persona pages were bursting with activity. Here the story was different [ ... ]. If we felt some doubt about our decision back then, the outpouring of sympathy and praise from these anonymous supporters -from Yemen and Egypt, India and Pakistan, Canada and Denmark-helped us overcome it" [17] (p. 97). As regards newsreels, they are forced to watch only those news that illustrate the "Islamophobia of the West and also its hypocrisy" [17] (p. 114). Finally, lack of communication and non-stop indoctrination often led people, to use the colloquial expression, to see the mote in their brother's eye without noticing the beam in their own. Jamilla and girls like her cannot stand MTV programs and Hollywood films: they find the sight of provocative sexy girls singing pop 
"sex-as-love" songs disgusting and consider situations in Hollywood films in which the hero or the heroine is surrounded by villains but manages to defeat them without much effort "predictable" and not at all "interesting or suspenseful" [17] (pp. 115-116). Paradoxically, they love instead nasheed singers and Amitabh Bachchan's Bollywood action dramas, "where the Indian superhero righted the wrongs of the world" [17] (p. 116). Therefore, it is not their content that they reject but their cultural wrapping, which caters for a specific audience with which they cannot possibly identify.

\subsection{The Desire for the West}

Islamist terrorism has gone global (see, for example, Gerges 2005 [27] and Moghadam 2008 [28]). In Baudrillard's words, the Islamists "have taken over all the weapons of the dominant power. [ ... ] They have assimilated everything of modernity and globalism, without changing their goal, which is to destroy that power" [16] (p. 19). Yet, in tune with Badiou's aforementioned contention, Khair's novel also makes it clear that the most powerful Daesh leaders, no matter whether they happen to be men or women, can conversely be seen as the ultimate embodiment of contradiction: they apparently condemn the luxuries of the West and threaten to do away with them altogether, but this in turn hides their obscure -and not necessarily conscious- desire to possess and enjoy them. In Just Another Jihadi Jane, two characters in particular can be given as an example of this reactive but at the same time intra-capitalist subjectivity: Hejjiye, the Muslim woman in charge of the Syrian orphanage where young women are trained to be jihadi brides and/or suicide bombers; and Hassan, the Daesh war lord that Ameena ends up marrying. From the very beginning, all women in the orphanage know that "Hejjiye was not someone you could offend openly" [17] (p. 95); she imposes a full schedule upon all the girls in order to prevent them from thinking and makes no secret of the fact that she is the highest authority there and nobody should dare to contradict her. She keeps on accusing the West of all evils but is quite familiarized with all the "basic Western norms" [17] (p. 145), especially when trying to lure western women into becoming part of their movement. Moreover, her unwavering confidence and enthusiasm, even when she is unable to contact her husband for days, seems to be rather "robotic": her "perfect posture, incredible balance, eyes giving nothing" blur the barrier between show and reality, to the point that she often looks like "models on a catwalk" [17] (p. 134). Her office, with "an executive table with built-in drawers and leather chairs at the end of the room" [17] (pp. 122-123) is no different from the ones one can find in many multinational/western corporations and firms. Finally, to make her desire for western luxuries even more conspicuous, she is very fond of posting photos of herself with "her dusky Chartreux cat" and "her collection of Gucci handbags" [17] (p. 56). As regards Hassan, he shows "a surprising interest in and knowledge of, Western fashion brands" [17] (p. 152). Like most Daesh leaders, who are often allowed to spend lots of money on expensive honeymoons [17] (p. 151), Hassan, a sort of deputy governor of the town, can afford to have more than one wife, has "a full house to himself and his family," a couple of female domestic servants and a slave, "a Yazidi boy, not much older than ten" [17] (p. 159), whom he keeps on abusing and humiliating till he finally beheads him after realizing that Ameena, out of love and compassion, had tried to protect the boy by hiding him into a well. The disenchanted Jamilla who dares to question everything right at the end of the novel goes as far as to describe Hassan as a "careerist," for whom killing is his corporate job [17] (p. 191) and "a free-market capitalist" who believes "in choice of a sort" as long as it is "limited" [17] (p. 211). He laughs at the fighters whom he labels as "pillheads," that is, those who have to take capsules of Captagon before going to battle [17] (p. 165), but makes sure that his favorite wife (certainly not Ameena!) and children are "safely quartered with his parents in Riyadh" [17] (p. 158). Hejjiye's hypocrisy is just as insulting: she affirms that, if she did not have so many responsibilities here on earth, she would gladly become a suicide bomber so as to enter and enjoy Paradise [17] (p. 193), but the fact is that she always makes sure that others sacrifice their lives so that she can stay alive. Jamilla's words openly denounce that there is no difference between western capitalist leaders and Islamist leaders like her:

She could have been a politician in Europe, justifying racist immigration laws in the most humane terms; she could have been a corporate head in New York, or a banker in Tokyo. [ ... ] It was 
only a fluke, I felt, that Hejjiye had been born in circles where the route to power lay through the strictures of Islam. Yes, people like her always manage to be driven to safety while someone else dies for their cause [17] (p. 205).

Violence is the weapon they all use to impose their will, camouflage their impossible blend of criminal heroism and western luxuries and encourage their regressive religious fundamentalism, which thus becomes nothing but an excuse, a cover. Although, as Khair's novel intends to show, Daesh is a revolutionary movement on an international scale with a clear secular agenda, namely, to protest on behalf of the poor and oppressed and to free Muslim lands from the postcolonial influence of the West, it is undeniable that religious beliefs have played a fundamental role in its emergence and development. Well-known scholars such as Patrick Sookhdeo explain [10] (pp. 234-237) that Al Qaeda, and by extension Daesh ideology, belong to the radical wing of Islamism known as Salafi-Jihadism, which has two main ideological sources: (a) Muslim Brotherhood ideology as promulgated by Sayyid Qutb, the main ideologue of the movement in the 1950s and 1960s; and (b) Wahhabi-Salafi ideology. Qutb believed that the biggest crisis in the contemporary world is the return of humanity to the immoral paganism of the pre-Islamic age of ignorance and the subsequent dethroning of God from his rightful sovereignty and rule. He also claimed that the first step towards Islamic renewal was the judging of all societies by the criterion of their adherence to the doctrine of God's sovereignty, as revealed by their implementation of sharia and their repudiation of western-influenced legal systems. All those that did not fulfil this criterion were to be excommunicated (tafkir) and denounced as jahili, and jihad had to be used to annihilate them and replace them by true Muslim regimes. Qutb's reinterpretation undoubtedly paved the way for indiscriminate terror. As regards Wahhabi-Salafi ideology, Wahhabi Islam is the dominant form of state Islam in Saudi Arabia. It is linked to Salafism, which rejects the schools of law and later developments in Islam and demands a return to the early model of Muhammad, his Companions (the salaf) and their followers. Salafis limit religious authority to the Koran, which they interpret in a literalist manner. Wahhabi Salafism has supported most radical Muslim groups around the world and in particular Salafi-Jihadis, which have thus increased their power and escalated their slide into terrorism. For more information on the origins of Salafist Islamist thinking and its use of religion as a means to achieve political ends see Wright 2006 [29] and McCants 2015 [30]. Once again, Khair's novel insists on the fact that, for many Daesh leaders religion, contrary to what might seem at first sight, is nothing but an excuse to impose their reign of terror. As a matter of fact, Hassan has no respect for Ameena's scholarly reading of Islam; "his was a technical Islam [ . . . ] a do-it-yourself manual [ ... ] concerned not with theory but with application, not with thought but with practice" [17] (p. 162). And the practice is no other than intense, massive and gratuitous violence, even against orthodox Muslims whose interpretation of Islam differed from his:

He would personally behead any traitor and would order all the families, including his own, to witness the beheading, caning any child above ten who refused to look. Given the choice between a lesser punishment and a greater one, he inevitably chose the gorier option. [ ... ] he looked truly happy only when he left and execution [ ... ] his face splattered with blood [17] (pp. 163-164).

To give but one example, this is what he does to the Rashidi clan who refuses to turn over an enemy soldier because he sought their protection and this accordingly obliged them to defend his life upon their honor. Furthermore, all traditional Muslim celebrations and festivals are forbidden -just as smiling- and books by orthodox Islamic scholars who eventually fell out of favor with Daesh are mercilessly purged, burnt up. Hejije is no better than Hassan, as her cruel treatment of Halide, the Turkish orphan who "was willing to allow herself more leeway in some matters" [17] (p. 115) and could not possibly approve of suicide bombers, clearly shows. Their narrow-mindedness prevents them from accepting any other interpretation of Islam; according to the Daesh leaders, it is only up to them to decide what God actually wants, as if this, the Peshmerga hostages wonder, were at all 
possible [17] (p. 142). Bigotry always ends up imposing itself, as it allows for no possible dialogue or exchange of ideas. As the mature Jamilla concludes:

You cannot really discuss moderate faith with someone who has an immoderate version of it. Any such discussion gets taken over by the person who holds the religious high ground and you either have to relinquish all claim to faith -which leaves you nowhere in such a debate or you have to scramble for higher theological ground, which makes your rational objections disappear or seem unsound [17] (p. 40).

Hatred and violence are practiced in the name of a religion that advocated peace in its original designation, and intolerance has replaced the mercy and forgiveness that allegedly characterized God's nature.

\subsection{Suicide Bombers}

The phenomenon of suicide bombing is so difficult to understand and assimilate, at least from a western perspective, that it has been widely analyzed from different angles by a high number of critics, none of whom has fully succeeded in providing a conclusive explanation (see, for example, Hassan 2011 [31], Bloom 2005 [32], Gambetta 2005 [33], Skaine 2013 [34], Reuter 2004 [35], Pape 2006 [36], Pedahzur 2005 [37], Khosrokhavar 2005 [38], Cook and Allison 2007 [39]). In tune with these critics' considerations, Khair's novel highlights the elusive nature of using one's own life as a weapon. Jamilla's final doubts about Ameena's alternative fate, had the latter been allowed to have a choice-“'What would she have wished [ ... ]? I don't know. Do you?" [17] (p. 219)- and, above all, Jamilla's deep consternation over her friend's final immolation, leave a number of questions hanging in the air, the same thorny questions that Talal Asad strives to answer when meditating on the ultimate motives and consequences of suicide bombing. In the first place, Asad [4] (pp. 40-45) wonders if there is a crucial difference between someone who kills in order to die and someone who dies in order to kill. As he sees it, one thing remains clear: whereas the end of suicide is killing oneself, the end of suicide bombing is killing oneself and others at the same time. This substantial difference leaves considerable scope for interpretation; obviously, it is not the effect of the bombing that baffles westerners but rather the bomber's motivation for doing such a thing. Very often, this suicidal act is attributed to some kind of pathology or alienation resulting from the systematic deprivation and humiliation suffered by the bomber. Secondly, this kind of actions are usually ascribed to the highly ritualized proclamation of death concomitant with radical Islamist faith; in other words, they are regarded as some kind of religious sacrifice. Yet, as Hassan insists [31] (p. 2), a clear distinction should be made between many suicide bombers and the groups that recruited them. To quote his own words:

Studies by serious scholars show that suicide bombing attacks are linked more to politics than to religion. Religion is used effectively by a number of Islamic radical groups to recruit suicide bombers and to raise operational funds but the leadership of these groups have secular goals, such as the expulsion of occupying forces from the 'homeland.' Thus, even if some suicide bombers are irrational or fanatical, the leadership of the groups that recruit and direct them is not.

At first sight, this is what Khair's novel apparently suggests: Ameena radicalized her religious beliefs mainly on account of the fact that she had a dysfunctional family and felt rather lonely and rejected in England; once in the Syrian orphanage, the Daesh leaders insist on claiming that the girls who blow themselves up have "'martyred' [themselves] for the cause" [17] (p. 119), that is, they have given up their lives as a sacrifice for the perpetuation of the Islamist faith and values. This kind of interpretations, Asad goes on to argue, define the bomber as morally underdeveloped, that is, premodern, especially when s/he is compared with 'civilized' peoples, whose secular politics turn violence, whenever this is unavoidable, into something disciplined, reasonable and just. However, as Hassan explains, many suicide bombers are anything but erratic and mad, as they often have a very clear and thoroughly elaborated political agenda: 
Suicidal behavior in a variety of settings may be used [ ... ] as a means to achieve multiple ends, including self-empowerment in the face of powerlessness, redemption in the face of damnation and honor in the face of humiliation. [ . . . ] This is central to a more meaningful understanding and explanation of contemporary suicide bombings [31] ((p. 3); emphasis in original).

According to this, we should look at this phenomenon through a very different lens. In keeping with Hassan's and May Jayyusi's contention, Asad claims that suicide bombers should be understood in terms of "new forms of political subjectivity that have been formed in the context of resistance to the particular powers that circumscribe them" [4] (p. 46). Drawing on Giorgio Agamben's well-known notion of the homo sacer and Hannah Arendt's belief that rage arises "only when there is reason to suspect that conditions could be changed and are not" [40] (p. 63), Jayyusi [41] and by extension Asad [4], conclude that the emphasis here should not be put on violence but rather on individual spontaneous action when legal political means are totally ineffective. After all, as Arendt argues and Asad corroborates, it is only the possibility of acting politically that makes us individuals and, therefore, human. In a word, these otherwise unintelligible acts make sense as long as they offer the individual/human being a secular form of immortality [4] (p. 47). "If homo sacer is he who can be killed and not sacrificed," Jayyusi [41] concludes, "then the martyr here inverses this relation to sovereignty, transforming himself into he who can be sacrificed but not killed." Roxanne Euben reinforces the point made by these critics by affirming that suicide bombing should be seen as a rather more complex phenomenon, namely, as a form of political action in which the pursuit of immortality is inexorably linked to a deeply this-worldly mission: to found or recreate a just community on earth-what Islam labels as the umma - in a particular historical moment [4] (p. 56). Paradoxically enough, Asad insists [4] (p. 63), the suicide bomber somehow partakes of a modern western tradition of armed conflict for the defense of a free political community, whereby saving the nation/the community may sometimes imply acting without abiding by ordinary moral constraints. Love is, without doubt, the main reason why Ameena becomes a suicide bomber, not religion: on the one hand, she feels the compulsive need to save her friend -she feels in debt with Jamilla, whose life is at risk because of her insistence that both of them should go to Syria and join the jihad; on the other, she desperately wants to revenge Sabah's cruel murder at the hands of Hassan -the name of this boy was, significantly, the last word Ameena cried before detonating her bomb. By immolating herself, Ameena prevents Hassan from perpetrating any more crimes and allows Jamilla to make a fresh start, far away from all that butchery, thus corroborating what Umm Layth, the old and kind Daesh widow, contentiously affirmed, namely, that "the role of a woman is to give birth, not to throw bombs" [17] (p. 202). Ironically, in Ameena's case the one and only way to give birth is by means of killing herself and those who had so adamantly tried to break and destroy women like her in all possible ways.

As for the reasons why suicide bombing inspires dread and, ultimately, horror Jacqueline Rose [42] takes it that horror seems to be associated with the fact that the attacker also dies. Perhaps, she says, "the revulsion stems partly from the unbearable intimacy shared in their final moments by the suicide bomber and her or his victims. Suicide bombing is an act of passionate identification -you take the enemy with you in a deadly embrace." It is the dissolution of the human body that generates horror. In Purity and Danger, Mary Douglas [43] explains the reasons for this: in every culture, primitive and modern alike, things are clearly categorized according to distinctive criteria whose confusion is regarded as an outrage. Whenever boundaries are crossed and breached, they must be restored so that law and order are once again established. Suicide bombing deliberately transgresses the barrier between different human beings, between human and inhuman, between life and death, in a word, between this world and the next and it is this grotesque blending that arouses horror. Last but not least, it must be taken into account that suicide is, per se, a most frightening act because, as Asad affirms, it is "a sin [ ... ] a unique act of freedom, a right that neither the religious authorities nor the nation-state allows" [4] (p. 67). Given the fact that in all religions the power over life and death can only be held legitimately by God and then by God's delegates here on earth, who are alone consequently entitled to inflict all sorts of punishment, including death, individuals have no right to kill themselves. Suicide therefore 
becomes an act of utmost disobedience and transgression, "the limitless pursuit of freedom, the illusion of an uncoerced interiority that can withstand the force of institutional disciplines" [4] (p. 91). As was argued before, Ameena's suicide is her final and definitive act of transgression and rebellion against a movement that literally did away with all of her dreams and ideals, a regime that took its hypocrisy and falsehood to the very extreme, even by dividing young women into two groups: that of the beautiful and innocent, whom they trained to become jihadi wives; and that of the "unattractive girls" and "those who had witnessed such violence done to them or theirs that it had dried up everything in their hearts except the thirst for revenge" [17] (p. 181).

\section{Conclusions}

As this analysis has tried to show, Khair's novel strives to illustrate that Islamist terrorism should not be exclusively understood as the by-product of a 'clash of civilizations' (West vs. Islam in this case), nor as the underside of the 'just' wars waged by 'civilized' nation-states. Instead, it should be regarded as the predictable consequence of countless unfair western policies in the Middle East over decades and, more recently, as the inexorable outcome of the triumph of globalization and unbridled capitalism on a worldwide scale. Such was the dialectic of domination imposed by the West for so long that, as Baudrillard contends [16] (pp. 69-70), the omnipresent threat of terrorism has drastically subverted the master-slave relationship upon which western power relied. In the past, it was the master who was exposed to death and could play with it, whereas the slave, deprived of death and a future, was doomed to sheer survival and labor. Today, it is the powerful westerners, overprotected and allegedly sheltered from death, who occupy the position of the slave, while those who are not afraid of dying, since mere survival is not their exclusive aim, are the ones who symbolically occupy the position of the master. Once again, extremes meet and the barrier civilized/barbarian blurs in front of our eyes: western civilization has always relied on exclusion and brutality and those who claim to fight against western violence usually end up inflicting the same cruelty, if not more, upon all those who fail to comply with their norms (non-radical Muslims included), or upon social sectors which, like women's, happen to be far too vulnerable and alienated to see through their oppressors' lies. In addition, they often condemn western luxuries as the very source of evil when, deep down in their hearts, they wish they could also enjoy them.

In tune with Asad's views [4] (p. 72), Khair's novel could also be said to argue that, despite claims to the contrary, the wound of terrorism is not so recent, as it originated in the historical defeat of communism, this being understood as the strategic thought that countered the hegemony of capitalism. Should things remain as they are, then, the idea of extirpating terrorism is a total fallacy. As Hassan insists [31] (pp. 1-2), the key rationale used by the United States and its allies to win public support for their wars, namely, that terrorist attacks can only be prevented through the democratization and liberalization of Muslim countries, has proved to be totally wrong, as these externally imposed policies "are likely to sharpen religious and ideological divisions in the world, especially in the recipient Muslim countries." New ways of thinking, new alliances, new egalitarian trajectories and encounters will be required to overcome contemporary rampant fascization and transcend the domination of globalized capitalism without falling into nihilism, "that murderous avatar of desire for the West," to quote Asad's words [4] (p. 74) once again by way of conclusion.

Just Another Jihadi Jane has managed to bring all of these contradictory issues to the fore. The ordeal suffered by both female protagonists, together with their resilience and the care they show for each other which, in Ameena's case, goes as far as entailing her own death, clearly denounce the lethal forces at work in our contemporary world. On the other hand, their respective fates also make a plea for an ethical encounter with the Other, a feminist ethics of care that can alone put an end to the vicious circle to which humanity has fallen prey, thus paving the way for some potential global understanding and compassion in the future.

Funding: The research carried out for the writing of this article is part of a project financed by the Spanish Ministry of Economy, Industry and Competitiveness (MINECO) in collaboration with the European Regional 
Development Fund (DGI/ERDF) (code FFI2017-84258-P), and another financed by the Centro Universitario de la Defensa Zaragoza (CUD2017-01). The author is also grateful for the support of the Government of Aragón and the European Social Fund (ESF) (code H03_17R).

Conflicts of Interest: The author declares no conflict of interest.

\section{References}

1. Münkler, H. The New Wars, 1st ed.; Polity: Cambridge, UK, 2005; ISBN 978-3-9810846-4-1.

2. Kaldor, M. New and Old Wars, 1st ed.; Polity: Cambridge, UK, 2006; ISBN 9780745655635.

3. Gray, C.H. Postmodern War: The New Politics of Conflict, 1st ed.; Guilford Press: New York, NY, USA, 1997; ISBN 139781572301764.

4. Asad, T. On Suicide Bombing, 1st ed.; Columbia University Press: New York, NY, USA, 2007; ISBN 978-0-231-14152-9.

5. Guelke, A. The Age of Terrorism and the International Political System, 1st ed.; Tauris Academic Publishers: London, UK, 1995; ISBN 9781845118037.

6. Kubiac, A. Stages of Terror: Terrorism, Ideology and Coercion as Theatre History, 2nd ed.; Open University Press: Buckingham, UK, 1992; ISBN 0-253-20663.

7. Zulaica, J.; Douglass, W. Terror and Taboo: The Follies, Fables and Faces of Terrorism, 1st ed.; Routledge: London, UK; New York, NY, USA, 1996; ISBN 84-493-0635-9.

8. Walzer, M. Arguing about War, 1st ed.; Yale University Press: New Haven, CT, USA; London, UK, 2004; ISBN 13:978-0-300-10978-8. (pbk).

9. Badiou, A. Our Wound is Not so Recent: Thinking of the Killings of 13 November, 1st ed.; Mackay, R., Trans.; Polity Press: Cambridge, UK; Malden, MA, USA, 2016; ISBN 13 978-1-5095-1493-9.

10. Sookhdeo, P. Ideas Matter: How to Undermine the Extremist Ideology Behind Al Qaeda. In Toward a Grand Strategy against Terrorism, 1st ed.; Harmon, C.C., Pratt, A.N., Gorka, S., Eds.; McGraw-Hill: New York, NY, USA, 2011; pp. 228-251. ISBN 978-0-07-352779-6.

11. Harris, L. Civilization and Its Enemies: The Next Stage of History, 1st ed.; Free Press: New York, NY, USA, 2004; ISBN 139781451655339.

12. Said, E. Covering Islam: How the Media and the Experts Determine How We See the Rest of the World, 2nd ed.; Vintage Books: London, UK, 1997; ISBN 978-0-09-959501-4.

13. Maalouf, A. Disordered World: A Vision for the Post-9/11 World, 2nd ed.; Bloomsbury: London, UK; New Delhi, India; New York, NY, USA; Sydney, Australia, 2012; ISBN 978-1-4088-2244-9.

14. Mishra, P. From the Ruins of Empire: The Revolt against the West and the Remaking of Asia, 2nd ed.; Penguin Books: London, UK, 2013; ISBN 978-0-241-95466-9.

15. Hafez, M. Why Muslims Rebel, 1st ed.; Lynne Rienner Publisher: London, UK, 2003; ISBN 1-58826-124-7.

16. Baudrillard, J. The Spirit of Terrorism, 2nd ed.; Turner, C., Trans.; Verso: London, UK; New York, NY, USA, 2003; ISBN 1-85984-448-0.

17. Khair, T. Just Another Jihadi Jane, 1st ed.; Periscope: Reading, UK, 2016; ISBN 9781902932545.

18. Kassam, Z.R. Women and Islam, 1st ed.; Praeger: Westport, CT, USA; London, UK, 2010; ISBN 9780275991586.

19. Hafez, S. An Islam of Her Own: Reconsidering Religion and Secularism in Women's Islamic Movements, 1st ed.; New York University Press: New York, NY, USA, 2011; ISBN 9780814773048.

20. Taylor, U.Y. The Promise of Patriarchy: Women and the Nation of Islam, 1st ed.; University of North Carolina Press: Chapel Hill, NC, USA, 2017; ISBN 9781469633930.

21. Falah, G.-W.; Nagel, C. Geographies of Muslim Women: Gender, Religion and Space, 1st ed.; Guilford Press: New York, NY, USA, 2005; ISBN 1-57230-134-1.

22. Eickelman, D.F.; Anderson, J.W. (Eds.) New Media in the Muslim World: The Emerging Public Sphere, 1st ed.; Indiana University Press: Bloomington, IN, USA, 2003; ISBN 13 978-0253216052.

23. Bunt, G.R. iMuslims: Rewiring the House of Islam, 1st ed.; Hurst: London, UK, 2009; ISBN 9789839541694.

24. Roy, O. Globalised Islam: The Search for a New Ummah, 1st ed.; Hurst: London, UK, 2004; ISBN 9781850655985.

25. Mandaville, P.G. Transnational Muslim Politics: Reimagining the Umma, 1st ed.; Routledge: London, UK; New York, NY, USA, 2001; ISBN 9780415246941.

26. Larsson, G. (Ed.) Religious Communities on the Internet: Proceedings from a Conference, 1st ed.; Swedish Science: Uppsala, Sweden, 2006; ISBN 9780195390155. 
27. Gerges, F.A. The Far Enemy: Why Jihad Went Global, 1st ed.; Cambridge University Press: Cambridge, UK, 2005; ISBN 10 0-511-16141-7.

28. Moghadam, A. The Globalization of Martyrdom, 1st ed.; Johns Hopkins University Press: Baltimore, MD, USA, 2008; ISBN 9781421400587.

29. Wright, L. The Looming Tower: Al-Qaeda and the Road to 9/11, 1st ed.; Alfred, A. Knopf: New York, NY, USA, 2006; ISBN 1400030846.

30. McCants, W. The ISIS Apocalypse: The History, Strategy and Doomsday Vision of the Islamic State, 1st ed.; St Martin's Press: New York, NY, USA, 2015; ISBN 9781250112644.

31. Hassan, R. Suicide Bombings, 1st ed.; Routledge: London, UK; New York, NY, USA, 2011; ISBN 9780415588867.

32. Bloom, M. Dying to Kill: The Allure of Suicide Terror, 1st ed.; Columbia University Press: New York, NY, USA, 2005; ISBN 9780231133210.

33. Gambetta, D. Making Sense of Suicide Missions, 1st ed.; Oxford University Press: New York, NY, USA, 2005; ISBN 139780199276998.

34. Skaine, R. Suicide Warfare: Culture, the Military and the Individual as a Weapon, 1st ed.; Praeger: Westport, CT, USA; London, UK, 2013; ISBN 9780313398643.

35. Reuter, C. My Life as a Weapon. A Modern History of Suicide Bombing, 1st ed.; Princeton University Press: Princeton, NJ, USA, 2004; ISBN 0691117594.

36. Pape, R. Dying to Win, 1st ed.; Gibson Square Books: London, UK, 2006; ISBN 1400063175.

37. Pedahzur, A. Suicide Terrorism, 1st ed.; Polity Press: Cambridge, UK, 2005; ISBN 0-7456-3383-8.

38. Khosrokhavar, F. Suicide Bombers, 1st ed.; Pluto Press: London, UK, 2005; ISBN 9781404209770.

39. Cook, D.; Allison, O. Understanding and Addressing Suicide Attacks, 1st ed.; Praeger: Westport, CT, USA; London, UK, 2007; ISBN 0275992608.

40. Arendt, H. On Violence, 1st ed.; Allen Lane: London, UK, 1970; ISBN 13 978-0-71-390149-8.

41. Jayyusi, M. Subjectivity and Public Witness: An Analysis of Islamic Militance in Palestine. In Proceedings of the SSRC Beirut Conference on the Public Sphere in the Middle East, Beirut, Lebanon, 22-24 October 2004. Unpublished Paper.

42. Rose, J. Deadly Embrace. Lond. Rev. Books 2004, 26, 21-24. Available online: https://www.lrb.co.uk/v26/ $\mathrm{n} 21 /$ jacqueline-rose/deadly-embrace (accessed on 2 July 2018).

43. Douglas, M. Purity and Danger: An Analysis of Concepts of Pollution and Taboo, 1st ed.; Routledge and Kegan Paul: London, UK, 1966; ISBN 978-0-41-528995-5. 